\title{
Dagleg hreyfing og punglyndiseinkenni eldra fólks í dreifbýli og péttbýli á Norðurlandi: Lýðgrunduð rannsókn
}

Birgitta R. Smáradóttir sjúkrabjálfari

Gísli K. Kristófersson² geđhjúkrunarfræđingur

Árún K. Sigurđardóttir ${ }^{2,3}$ hjúkrunarfræđingur

Sólveig Á. Árnadóttiri, öldrunarsjúkrapjálfari

'Námsbraut í sjúkrapjálfun, heilbrigðisvísindasviði Háskóla Íslands, ${ }^{2}$ hjúkrunarfræðideild, heilbrigðisvísindasviði Háskólans á Akureyri, ${ }^{3}$ deild mennta og vísinda á Sjúkrahúsinu á Akureyri, "rannsóknarstofu í hreyfivísindum, námsbraut í sjúkrapjálfun. Háskóla Íslands.

Fyrirspurnum svarar Sólveig Á. Árnadóttir, saa@hi.is

\section{Inngangur}

Hlutfall eldri borgara af heildarmannfjölda fer vaxandi með hverju ári sem líður. ${ }^{1}$ Einstaklingar í pessum aldurshópi eru líklegri en peir sem yngri eru til að hafa langvinna sjúkdóma ${ }^{1}$ og færniskerðingar og pví geta fylgt punglyndiseinkenni sem draga úr lífsgæðum á efri árum. ${ }^{2}$ Fjöldi rannsókna styðja við kosti hreyfingar í glímunni við alla pessa pætti og ótímabæra öldrun. Í mörgum rannsóknanna hefur verið lögð áhersla á reglulega pjálfun í frístundum og niðurstöður meðal annars rennt stoðum undir pað að meiri hreyfing, í pess konar aðstæðum, dragi helst úr líkum á punglyndi hjá eldra fólki. ${ }^{3}$

Nútímaráðleggingar um hreyfingu ná yfir allar athafnir daglegs lífs sem kalla á líkamlega áreynslu og vöðvavinnu sem skilar sér í orkueyðslu umfram pað sem parf í hvíld. ${ }^{4}$ Pannig takmarkast fræðihugtakið „hreyfing“ (physical activity) ekki við frístundatíma heldur nær pað einnig til daglegrar hreyfingar í annars konar aðstæðum eins og við heimilisstörf og atvinnu sem reynir á líkamann. Pótt pessi skilgreining á hreyfingu endurspeglist í mörgum rannsóknum á heilsu og hreyfingu eldra fólks ${ }^{5,6}$ vantar rannsóknir á heilsueflandi áhrifum hreyfingar í mismunandi aðstæðum daglegs lífs. Til dæmis vantar fleiri rannsóknir á pví hvort hreyfing í öðru samhengi en frístundum geti dregið úr punglyndi hjá eldri borgurum. ${ }^{7}$

Búseta er dæmi um umhverfispátt sem getur tengst lífsstíl og heilsu íbúanna. Niðurstöður rannsókna á eldra fólki sem býr í

\section{Á G R I P}

\section{INNGANGUR}

Markmið rannsóknarinnar var að kortleggja daglega hreyfingu við mismunandi aðstæður (frístundir, heimilisstörf og vinnu), hjá eldri ( $\geq 65$ ára) Norðlendingum sem búa heima, og rýna í tengslin á milli daglegrar hreyfingar og punglyndiseinkenna. Einnig voru rannsökuð áhrif búsetu, kyns eđa aldurshóps.

\section{EFNIVIĐUR OG AĐFERĐIR}

Gögnum var safnað í september 2017 til janúar 2018 í lýðgrundaðri pversniðsrannsókn með lagskiptu slembiúrtaki. Pátttakendur voru 175 (svarhlutfall $57,9 \%$ ), á aldrinum $65-92$ ára, $43 \%$ voru konur og $40 \%$ búsett í dreifbýli. Spurningalistinn Physical Activity Scale for the Elderly (PASE) var notaður til að̃ meta daglega hreyfingu. Hann skiptist í heildarkvarđa og prjá undirkvarđa sem meta hreyfingu við frístundir. heimilisstörf og vinnu sem reynir á líkamann. Spurningalistinn Geriatric Depression Scale var notaður til að meta punglyndiseinkenni.

\section{NIĐURSTÖĐUR}

Heildarhreyfing tengdist ekki búsetu en karlar hreyfðu sig meira en konur og yngri aldurshópur (65-74 ára) meira en eldri (75-92 ára). Stærstur hluti heildarhreyfingar hjá öllum hópum tengdist heimilisstörfum. Karlar hreyfðu sig meira en konur við heimilisstörf. dreifbýlisbúar hreyfðu sig meira en péttbýlisbúar við vinnu og yngri aldurshópur meira við vinnu en sá eldri. Aukin heildarhreyfing og aukin hreyfing samkvæmt undirkvörðum PASE tengdist minni punglyndiseinkennum. Hreyfing í frístundum var pó eini undirkvarðinn sem hafði sjálfstæð tengsl við minni punglyndiseinkenni pegar tekið var tillit til annarra undirkvarða PASE.

\section{ÁLYKTANIR}

Rannsóknin varpar mikilvægu ljósi á daglega hreyfingu eldri Norðlendinga og hvernig punglyndiseinkenni á efri árum tengjast hreyfingu í mismunandi aðstæðum daglegs lífs. Niðurstöðurnar styðja alpjóðlegar rannsóknir sem hafa sýnt sterk jákvæð áhrif reglulegrar hreyfingar í frístundum á geð̌heilsu. 
Tafla I. Bakgrunnur allra pátttakenda eftir búsetu peirra í péttbýli og dreifbýli, kyni og aldurshópi.

\begin{tabular}{|c|c|c|c|c|c|c|c|c|c|c|}
\hline \multicolumn{11}{|l|}{ Medaltal (SF) [Spönn] eda N $\left(\%{ }^{*}\right)$} \\
\hline Bakgrunnur & $\begin{array}{l}\text { Heildarfjöldi } \\
\mathrm{N}=175\end{array}$ & $\begin{array}{l}\text { péttbýli } \\
\mathrm{n}=105\end{array}$ & $\begin{array}{l}\text { Dreifbýli } \\
n=70\end{array}$ & p-gildi & $\begin{array}{l}\text { Karl } \\
n=100\end{array}$ & $\begin{array}{l}\text { Kona } \\
n=75\end{array}$ & p-gildi & $\begin{array}{l}65-74 \text { ára } \\
n=104\end{array}$ & $\begin{array}{l}75-92 \text { ára } \\
\mathrm{n}=71\end{array}$ & p-gildi \\
\hline \multicolumn{11}{|l|}{ Einstaklingspættir } \\
\hline Eldri aldurshópur (75-92 ára) & $71(41)$ & $44(42)$ & 27 (39) & 0.662 & $45(45)$ & $26(34,7)$ & 0.17 & & & \\
\hline Kyn, karlar & $100(57)$ & $63(60)$ & $37(53)$ & 0,352 & & & & $55(52,9)$ & $45(63,4)$ & 0.168 \\
\hline Menntun, ár & $\begin{array}{l}11,1(5,3) \\
{[0-30]}\end{array}$ & $\begin{array}{l}12,5(5,2) \\
{[1-30]}\end{array}$ & $\begin{array}{l}9(4,7) \\
{[2-24]}\end{array}$ & $<0,001$ & $\begin{array}{l}11,2(5,5) \\
{[1-30]}\end{array}$ & $\begin{array}{l}10,8(4,9) \\
{[3-24]}\end{array}$ & 0,811 & $\begin{array}{l}12.1(5,3) \\
{[0-30]}\end{array}$ & $\begin{array}{l}9,5(4,85) \\
{[1-23]}\end{array}$ & 0,002 \\
\hline Fjöldi sjúkdóma & $\begin{array}{l}2.9(1.7) \\
{[0-9]}\end{array}$ & $\begin{array}{l}3.15(1,67) \\
{[0-8]}\end{array}$ & $\begin{array}{l}2,45(1.79) \\
{[0-9]}\end{array}$ & 0,009 & $\begin{array}{l}2,84(1,71) \\
{[0-8]}\end{array}$ & $\begin{array}{l}2,92(1,81) \\
{[0-9]}\end{array}$ & 0,765 & $\begin{array}{l}2,75(1,63) \\
{[0-7]}\end{array}$ & $\begin{array}{l}3,04(1,9) \\
{[0-9]}\end{array}$ & 0,289 \\
\hline $\begin{array}{l}\text { Punglyndismat fyrir aldrađa } \\
\text { (GDS) } 0-30\end{array}$ & $\begin{array}{l}5(3,8) \\
{[0-20]}\end{array}$ & $\begin{array}{l}4,9(3,7) \\
{[0-18]}\end{array}$ & $\begin{array}{l}4,9(4,1) \\
{[0-20]}\end{array}$ & 0.978 & $\begin{array}{l}5,16(4,18) \\
{[0-20]}\end{array}$ & $\begin{array}{l}4,53(3,27) \\
{[0-15]}\end{array}$ & 0.28 & $\begin{array}{l}4.42(3.73) \\
{[0-20]}\end{array}$ & $\begin{array}{l}5,6(3,86) \\
{[0-15]}\end{array}$ & 0,046 \\
\hline Punglyndi, 11+ stig á GDS & $16(9,4)$ & $10(9,5)$ & $6(9,1)$ & 0.925 & $11(11,3)$ & $5(6,7)$ & 0,311 & $6(5,8)$ & $10(14,7)$ & 0,605 \\
\hline \multicolumn{11}{|l|}{ Umhverfispættir } \\
\hline Búseta, dreifbýli & $70(40)$ & & & & $37(37)$ & $33(44)$ & 0,352 & $43(41,3)$ & $27(38)$ & 0,662 \\
\hline Búa einir & $40(22,9)$ & $29(27,6)$ & $11(15.7)$ & 0,066 & 19 (19) & $21(28)$ & 0.161 & $19(18,3)$ & $21(29,6)$ & 0.081 \\
\hline Starfandi & $46(26,3)$ & $21(20)$ & $25(36)$ & 0.021 & $32(32)$ & $14(18.7)$ & 0,048 & $39(37,5)$ & $7(9,9)$ & $<0,001$ \\
\hline Nota hjálpartæki innandyra & $4(2,3)$ & $2(1.9)$ & $2(3)$ & 0.654 & $2(2)$ & $2(2,8)$ & 0,746 & $4(3,8)$ & $0(0)$ & 0.104 \\
\hline Nota hjálpartæki utandyra & $34(19,4)$ & $19(18.1)$ & $15(21,4)$ & 0.585 & $15(15)$ & $19(25,3)$ & 0,087 & $12(11,5)$ & $22(31)$ & 0.001 \\
\hline Fjöldi lyfja & $\begin{array}{l}3(2,7) \\
{[0-10]}\end{array}$ & $\begin{array}{l}3.51(2,8) \\
{[0-10]}\end{array}$ & $\begin{array}{l}2,31(2,51) \\
{[0-10]}\end{array}$ & 0,004 & $\begin{array}{l}3.17(2,77) \\
{[0-10]}\end{array}$ & $\begin{array}{l}2,85(2,72) \\
{[0-10]}\end{array}$ & 0.451 & $\begin{array}{l}2,47(2,54) \\
{[0-10]}\end{array}$ & $\begin{array}{l}3,86(2,84) \\
{[0-10]}\end{array}$ & $<0,001$ \\
\hline \multicolumn{11}{|l|}{ Líkamsstarfsemi } \\
\hline Grunnhreyfifærni, sekúndur & $\begin{array}{l}10,36(2,759) \\
{[5-24]}\end{array}$ & $\begin{array}{l}10,1(2,468) \\
{[6-18]}\end{array}$ & $\begin{array}{l}10,78(3,145) \\
{[5-24]}\end{array}$ & 0.121 & $\begin{array}{l}10,21(2,35) \\
{[6-17]}\end{array}$ & $\begin{array}{l}10,56(3,23) \\
{[5-24]}\end{array}$ & 0.417 & $\begin{array}{l}9.78(2,48) \\
{[5-23]}\end{array}$ & $\begin{array}{l}11,24(2,95) \\
{[6-24]}\end{array}$ & $<0,001$ \\
\hline
\end{tabular}

*Hlutfall (\%) byggt á gildum gögnum fyrir hverja breytu. P-gildi gefa til kynna marktækan mun á milli bátttakenda eftir búsetu, kyni eđa aldurshópi. Punglyndiseinkenni voru metin með GDS (Geriatric Depression Scale) og líkamleg færni var metin með TUG (Timed Up and Go). N stendur fyrir heildarfjöldi, n fyrir breytu og SF stendur fyrir staðalfrávik.

heimahúsum benda til pess að miðað við péttbýlisbúa glími dreifbýlisbúar frekar við punglyndi, verri líkamlega færni og fleiri heilsutengd vandamál. ${ }^{5,8}$ Pá hafa rannsakendur hér á landi ${ }^{5}$ og víðar ${ }^{10}$ sýnt fram á að miðað við dreifbýlisbúa stundi péttbýlisbúar frekar reglubundna hreyfingu í frístundum. Meðal eldri Norðlendinga voru hins vegar jákvæð tengsl á milli búsetu í dreifbýli og meiri líkamlegrar áreynslu við vinnu og meirihluti af heildarhreyfingu tengdist heimilisstörfum, óháð búsetu. ${ }^{5}$

Pörf er á frekari rannsóknum á heildarhreyfingu eldri Íslendinga, hreyfingu í mismunandi aðstæðum og hvers konar hreyfing getur dregið úr punglyndi á efri árum. Meginmarkmið pessarar rannsóknar voru pví: (1) að kortleggja heildarhreyfingu eldri Norðlendinga og hreyfingu í mismunandi aðstæðum (tengda frístundum, heimilisstörfum og vinnu), (2) að rýna í tengsl milli hreyfingar og einkenna punglyndis og (3) rannsaka hvort niðurstöðurnar tengdust búsetu í dreifbýli eða péttbýli, kyni eða aldurshópi.

\section{Efniviður og aðferðir}

Petta rannsóknarverkefni var afmarkaður hluti af lýðgrundaðri pversniðsrannsókn á heilsu og aðstæðum eldri Norðlendinga. Gagnaöflun fór fram frá september 2017 til janúar 2018. Ítarlegri lýsing á rannsóknaraðferð hefur verið birt á öðrum vettvangi. ${ }^{11}$

\section{Val á pátttakendum}

Pátttakendur purftu að vera að minnsta kosti 65 ára, að búa heima (utan stofnana) og hafa nægilega tjáskiptafærni til að geta ákveðið stund og stað fyrir rannsóknarviðtal og mælingar. Lagskipt slembiúrtak (aldur, kyn, búseta) með 395 einstaklingum var dregið úr Pjóðskrá Íslands. Af pessum 395 reyndist ekki mögulegt að ná í 73 einstaklinga og 20 uppfylltu ekki skilyrði um að búa heima. Alls 302 einstaklingar fengu sendar upplýsingar um rannsóknina og af peim sampykktu 175 (57,9\%) að taka pátt. Einstaklingar sem neituðu pátttöku voru svipaðir pátttakendum pegar litið var á aldur $(p=0,77)$ og búsetu $(p=0,55)$ en fleiri konur neituðu pátttöku en karlar $(p=0,01)$. Algengustu ástæður pess að vilja ekki taka pátt voru að vera of upptekin(n) og að hafa nýlega tekið pátt í öðrum rannsóknum.

\section{Rannsóknarsvæði}

Rannsóknarsvæðin á Norðurlandi voru valin með hliðsjón af skilgreiningu á péttbýlis- og dreifbýlisbúsetu á Íslandi. ${ }^{12}$ Pátttakendur sem bjuggu í péttbýli komu frá Akureyri og pátttakendur í dreifbýli voru úr Skagafirði (ekki Sauðárkróki) og Pingeyjarsýslum (ekki Húsavík).

\section{Staðlaðir spurningalistar fyrir hreyfingu og punglyndi}

Mat á líkamsvirkni aldraðra (Physical Activity Scale for the Elderly, 
PASE) er stuttur staðlaður spurningalisti ${ }^{13}$ sem var notaður til að meta hreyfingu liðinnar viku. Hann er bandarískur að uppruna, er til í íslenskri pýðingu ${ }^{14}$ og er sá spurningalisti sem einna helst er mælt með á alpjóðavísu. ${ }^{15}$ Spurningalistinn er sniðinn fyrir faraldsfræðilegar rannsóknir á eldri einstaklingum ( $\geq 65$ ára) sem búa heima og til að nema grunnpætti hreyfingar: (1) tegund hreyfingar og aðstæður, (2) tíðni, (3) hve lengi í einu og (4) ákefð. Spurningarnar 12 beinast að líkamlegri áreynslu í prennskonar aðstæðum sem er grunnurinn fyrir undirkvarða PASE. Frístundasamhengið (PASE-frístundir) nær yfir göngu utan heimilis; létta, miðlungserfiða og erfiða hreyfingu í ípróttum og öðrum frístundum (til dæmis dans, sund, hjólreiðar og golf). Heimilissamhengið (PASEheimili) nær yfir margvísleg létt og erfið heimilisstörf, viðhald á heimili, garðvinnu, snjómokstur og pað að vera í hlutverki óformlegs umönnunaraðila. Atvinnusamhengið (PASE-vinna) nær yfir líkamlega erfiða vinnu sem getur verið launavinna eða sjálfboðavinna. Í rannsókninni var fylgt stöðluðum leiðbeiningum fyrir PASE, reiknuð út stig fyrir einstaka undirkvarða og heildarstig fyrir hreyfingu (PASE-heild). Heildarstigin geta verið frá núll til 400 og jafnvel fleiri hjá ofurvirkum einstaklingum. Að auki reiknuðum við sérstaklega út stig fyrir PASE-göngu til að geta rýnt í pessa algengu tegund hreyfingar í frístundum.

Punglyndismat fyrir aldraða (Geriatric Depression Scale, GDS) $)^{16,17}$ var notað til að meta punglyndiseinkenni. Í pessum staðlaða sjálfsmatslista eru gefin 0 eða 1 stig fyrir hvert atriði og samanlögð stig geta spannað kvarðann frá núll til 30 (fleiri stig meiri punglyndiseinkenni) ${ }^{16}$ Byggt á rannsókn á upprunalegri bandarískri útgáfu GDS voru sett fram viðmið um að 11 eða fleiri stig bentu til punglyndis ${ }^{18}$ en byggt á íslenskri rannsókn var viðmiðið hærra, eða 14 stig. ${ }^{17}$

\section{Gagnaöflun}

Fjölfaglegt teymi leiddi rannsóknina og pjálfaði fjóra starfsmenn sem sáu um gagnaöflun. Pátttakendur gátu valið um að fá starfsmann heim eða hitta hann á rannsóknarstöð í grennd við heimili sitt. Rannsóknin var sampykkt af Vísindasiðanefnd (VSN-16-100) og allir pátttakendur skrifuðu undir upplýst sampykki áður en gagnaöflun hófst. Pátttakendur svöruðu bakgrunnsspurningum um menntun, sjúkdómsgreiningar, lyf, sambúðarform, atvinnu og notkun hjálpartækja. PASE, ${ }^{13}$ GDS $^{16}$ og grunnhreyfifærniprófið Tímamælt upp og gakk (Timed Up and Go, TUG), ${ }^{19}$ voru lögð fyrir pátttakendur samkvæmt stöðluðum leiðbeiningum.

\section{Tölfræði}

Jamovi-forritið var notað við tölfræðiútreikninga og miðað var við 95\% öryggismörk (ÖM) og 5\% marktektarmörk $(\mathrm{p}<0,05)$. Pátttakendum var skipt í tvo aldurshópa, yngri (65-74 ára) og eldri (7592 ára) og tvo GDS-hópa, ekki punglyndi (0-10 stig) og mögulegt punglyndi (11-30 stig). ${ }^{18}$ Fáir einstaklingar voru með 11 eða fleiri stig og pví var pessi tvennubreyta ekki notuð frekar í tölfræðigreiningu. Lýsandi tölfræði var notuð á breyturnar og pær síðan bornar saman eftir búsetu, kyni og aldurshópi með t-prófi óháðra hópa (samfelldar breytur), Mann-Whitney U-prófi (raðbreytur) og Pearson's kí-kvaðrat prófi (tvennubreytur). Línuleg aðhvarfsgreining (einföld og fjölpátta) var notuð til að rannsaka sambandið á milli PASE-kvarða og GDS. PASE-heild og PASE-heima uppfylltu skilyrði fyrir greininguna en umbreyta purfti PASE-frístundir og GDS með lógaritma. PASE-vinna var pað mikið skekkt að henni var skipt í tvennubreytu (líkamleg vinna, engin líkamleg vinna) og amband hennar við GDS rannsakað með tvíkosta lógístískri aðhvarfsgreiningu (einfaldri og fjölpátta).

Tafla II. Heildarhreyfing í daglegu lífi (PASE-heild) og hreyfing við mismunandi aðstæður (PASE-frístundir, PASE-heimili og PASE-vinna) greind eftir búsetu í péttbýli og dreifbýli, kyni og aldurshópi.

\begin{tabular}{|c|c|c|c|c|c|c|c|c|c|c|}
\hline \multicolumn{11}{|c|}{ Meðaltal (SF) [Spönn] eđa n $\left(\%^{*}\right)$} \\
\hline $\begin{array}{l}\text { Pátttaka í hreyfingu við } \\
\text { mismunandi aðstæður }\end{array}$ & $\begin{array}{l}\text { Heildarfjöldi } \\
\mathrm{N}=175\end{array}$ & $\begin{array}{l}\text { Péttbýli } \\
\mathrm{n}=105\end{array}$ & $\begin{array}{l}\text { Dreifbýli } \\
\mathrm{n}=70\end{array}$ & p-gildi & $\begin{array}{l}\text { Karl } \\
n=100\end{array}$ & $\begin{array}{l}\text { Kona } \\
\mathrm{n}=75\end{array}$ & p-gildi & $\begin{array}{l}65-74 \text { ára } \\
n=104\end{array}$ & $\begin{array}{l}75-92 \text { ára } \\
\mathrm{n}=71\end{array}$ & p-gildi \\
\hline PASE-heild, 0-400+ & $\begin{array}{l}138(80,9) \\
{[0-426]}\end{array}$ & $\begin{array}{l}130(73.7) \\
{[0-340]}\end{array}$ & $\begin{array}{l}150(89.8) \\
{[0-426]}\end{array}$ & 0.146 & $\begin{array}{l}152(80,8) \\
{[0-370]}\end{array}$ & $\begin{array}{l}120(77.9) \\
{[0-426]}\end{array}$ & 0.009 & $\begin{array}{l}155(85.9) \\
{[0-397]}\end{array}$ & $\begin{array}{l}114(66,6) \\
{[25-426]}\end{array}$ & $<0,001$ \\
\hline PASE-frístundir & $\begin{array}{l}28.2(30,1) \\
{[0-156]}\end{array}$ & $\begin{array}{l}24,7(25.5) \\
{[0-124]}\end{array}$ & $\begin{array}{l}33,4(35,4) \\
{[0-156]}\end{array}$ & 0.267 & $\begin{array}{l}29.5(29.4) \\
{[0-124]}\end{array}$ & $\begin{array}{l}26,5(31,1) \\
{[0-156]}\end{array}$ & 0,359 & $\begin{array}{l}30,8(32,3) \\
{[0-156]}\end{array}$ & $\begin{array}{l}24,4(26,2) \\
{[0-122]}\end{array}$ & 0.328 \\
\hline PASE-heimili & $\begin{array}{l}79.7(37,8) \\
{[0-171]}\end{array}$ & $\begin{array}{l}84,1(39,2) \\
{[0-171]}\end{array}$ & $\begin{array}{l}73.1(34,7) \\
{[0-151]}\end{array}$ & 0,208 & $\begin{array}{l}85,5(41,3) \\
{[0-171]}\end{array}$ & $\begin{array}{l}71,9(31,2) \\
{[0-141]}\end{array}$ & 0,016 & $\begin{array}{l}83,7(40,8) \\
{[0-171]}\end{array}$ & $\begin{array}{l}73,9(32,2) \\
{[25-151]}\end{array}$ & 0.053 \\
\hline PASE-vinna & $\begin{array}{l}30,2(54) \\
{[0-300]}\end{array}$ & $\begin{array}{l}21,0(42,8) \\
{[0-150]}\end{array}$ & $\begin{array}{l}43.9(65.4) \\
{[0-300]}\end{array}$ & 0.017 & $\begin{array}{l}36,8(57,9) \\
{[0-252]}\end{array}$ & $\begin{array}{l}21,4(47,3) \\
{[0-300]}\end{array}$ & 0.087 & $\begin{array}{l}40(56,9) \\
{[0-252]}\end{array}$ & $\begin{array}{l}15,7(46,2) \\
{[0-300]}\end{array}$ & $<0,001$ \\
\hline Líkamleg vinna & $61(34,9)$ & $30(28,6)$ & $31(44,3)$ & 0,033 & $39(39)$ & $22(29.3)$ & 0,186 & $48(46,2)$ & $13(18,3)$ & $<0,001$ \\
\hline PASE-ganga & $\begin{array}{l}15,2(18,2) \\
{[0-85,7]}\end{array}$ & $\begin{array}{l}13.3(15.0) \\
{[0-85.7]}\end{array}$ & $\begin{array}{l}18,2(22,0) \\
{[0-85,7]}\end{array}$ & 0,491 & $\begin{array}{l}15,6(17,9) \\
{[0-85,7]}\end{array}$ & $\begin{array}{l}14,7(18,8) \\
{[0-85,7]}\end{array}$ & 0,375 & $\begin{array}{l}17,4(19,9) \\
{[0-85,7]}\end{array}$ & $\begin{array}{l}12.1(15) \\
{[0-85,7]}\end{array}$ & 0,143 \\
\hline
\end{tabular}

*Hlutfall (\%) byggt á gildum gögnum fyrir hverja breytu. P-gildi <0,05 gefur til kynna marktækan mun á milli pátttakenda eftir búsetu, kyni eða aldurshópi. PASE-heild er heildarhreyfing samkvæmt staðlaða spurningalistanum Physical Activity Scale for the Elderly (PASE). PASE-frístundir. PASE-heimili og PASE-vinna eru undirkvarðar heildarhreyfingar á PASE par sem dagleg hreyfing er tengd frístundum, heimilisstörfum og vinnu sem reynir á líkamann og er ýmist launuð eða sjálfboðavinna. Líkamleg vinna á við alla pá sem stunda vinnu sem reynir meira á líkamann en kyrrsetuvinna. PASE-ganga á við pá hreyfingu í frístundum sem tengist göngu. 


\section{Niðurstöður}

Pátttakendur ( $\mathrm{N}=175)$ voru á aldrinum 65-92 ára, fleiri voru í yngri aldurshópi $(59 \%, \mathrm{n}=104)$ en peim eldri og péttbýlisbúar voru í meirihluta $(60 \%, n=105)$. Karlar voru fleiri $(57 \%, n=100)$ en konur. Í töflu I eru upplýsingar um bakgrunn pátttakenda og samanburður eftir búsetu, kyni og aldurshópi. Eldra fólk í péttbýli var líklegra til að hafa meiri menntun, vera hætt að vinna, hafa fleiri sjúkdóma og nota fleiri lyf en eldra fólk í dreifbýli. Karlar voru líklegri en konur til að vera ennpá starfandi á vinnumarkaði. Eldri aldurshópur var líklegri til að hafa minni menntun, lýsa fleiri punglyndiseinkennum, vera hættur að vinna, nota hjálpartæki utandyra, nota fleiri lyf og hafa skertari grunnhreyfifærni (mæld með TUG) en yngri aldurshópur.

Í töflu II eru niðurstöður úr PASE eftir búsetu, kyni og aldurshópi. Enginn munur var á PASE-heild eftir búsetu en karlar hreyfðu sig meira í heildina en konur og yngri aldurshópur hreyfði sig meira en sá eldri. Pegar litið var á hreyfingu við mismunandi aðstæður kom í ljós að PASE-frístundir og PASE-ganga voru sambærileg eftir búsetu, kyni og aldurshópi. Í dreifbýli var eldra fólk með fleiri stig á PASE-vinna en péttbýlisbúar og karlar fengu fleiri stig á PASE-heimili en konur. Yngri aldurshópurinn var líklegri til að fá fleiri stig tengd PASE-vinnu en peir sem voru eldri. Stærstur hluti hreyfingar tengdist heimilisstörfum (meðaltal 58\%) hjá öllum hópum í rannsókninni.

Í töflu III eru niðurstöður fjölpátta aðhvarfsgreiningar sem lýsa sambandinu á milli priggja bakgrunnsbreyta (búseta, kyn og aldurshópur) og hvers og eins PASE-kvarða fyrir sig. Par kom í ljós að breyturnar kyn og aldurshópur höfðu sjálfstæð tengsl við PASEheild og PASE-heimili, en búseta tengdist hvorugri af pessum PASE-breytum. Engin af bakgrunnsbreytunum hafði sjálfstæð tengsl við PASE $_{\log }$-frístundir eða PASE ${ }_{\log }$-göngu (niðurstöður ekki í töflu, $\mathrm{p}=0,127-0,559)$. Allar bakgrunnsbreyturnar voru með sjálf-

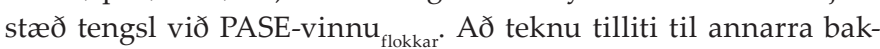
grunnsbreyta, voru einstaklingar búsettir í dreifbýli pví marktækt líklegri til að stunda vinnu sem reynir á líkamann en peir sem voru búsettir í péttbýli, yngri aldurshópur marktækt líklegri en peir í eldri aldurshópi og karlar marktækt líklegri en konur.

Í töflu IV eru niðurstöður einfaldrar línulegrar aðhvarfsgrein-

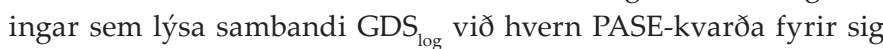

og niðurstöður fjölpátta línulegar aðhvarfsgreiningar sem varpa ljósi á sama samband pegar tekið er tillit til priggja bakgrunnsbreyta (búsetu, kyns og aldurshóps). Meiri hreyfing samkvæmt PASE-heild, PASE ${ }_{\text {log }}$-frístundir, PASE-heimili, PASE-vinna flokkar $_{\text {og }}$ PASE $_{\log }$-ganga tengdist í öllum tilfellum minni punglyndiseinkennum. Pegar tekið var tillit til bakgrunnsbreytanna búsetu, kyns og aldurhóps hélst áfram sambandið á milli minni punglyndiseinkenna og fleiri stiga á PASE-heild, PASE $_{\log }$-frístundir og PASE-heimili.

Í töflu V eru niðurstöður úr fjölpátta línulegri aðhvarfsgreiningu sem sýna hvernig meiri hreyfing í frístundum hafði sjálfstæð tengsl við minni punglyndiseinkenni, að teknu tilliti til hreyfingar við heimilisstörf og í vinnu. Petta sjálfstæða samband milli hreyfingar í frístundum og punglyndiseinkenna veiktist lítillega pegar tekið var tillit til búsetu, kyns og aldurshóps.

\section{Umræður}

Niðurstöður rannsóknarinnar varpa ljósi á hreyfingu í daglegu lífi eldri Norðlendinga sem búa í heimahúsum í dreifbýli og péttbýli, og hvernig hreyfingin byggir á líkamlegri áreynslu í frístundum, við heimilistörf og vinnu. Búseta, kyn og aldur höfðu áhrif á pað hversu mikið pátttakendur hreyfðu sig við heimilisstörf, í vinnu og í heildina. Hins vegar tengdist hvorki búseta, kyn né aldurshópur pví hversu mikið pátttakendur hreyfðu sig í frístundum. Aukin heildarhreyfing yfir daginn og hreyfing við mismunandi aðstæður tengist minni punglyndiseinkennum, en niðurstöðurnar benda til pess að hreyfing í frístundum hafi enn meira að segja fyrir geðheilsu en hreyfing tengd heimilisstörfum og vinnu.

Meðal pátttakenda voru fleiri karlar en konur. Petta er óvenjulegt í lýðgrunduðum rannsóknum á eldra fólki par sem konur lifa að jafnaði lengur en karlar. Skýringa má leita í pví að fleiri konur en karlar höfnuðu beiðni um að taka pátt í rannsókninni, fleiri eldri konur en karlar búa inni á hjúkrunarheimilum ${ }^{20}$ (og voru par af leiðandi ekki í rannsóknarúrtakinu) og hluti úrtaksins kom úr dreifbýli par sem gjarnan er hærra hlutfalli karla en kvenna. ${ }^{21}$ Varðandi bakgrunn pátttakenda var munur eftir kyni og aldurshópi almennt samhljóma fyrri rannsóknum en pó lýstu péttbýlisbúar fleiri sjúkdómsgreiningum en dreifbýlisbúar, sem

Tafla III. Dagleg hreyfing (heildarkvarði og undirkvarðar) og tengsl við bakgrunnsbreyturnar búseta, kyn og aldurshópur. Fjölpátta línuleg aðhvarfsgreining og fjölpátta tvíkosta aðhvarfsgreining.

\begin{tabular}{|c|c|c|c|c|c|c|c|c|c|c|c|c|c|c|c|c|}
\hline \multirow[b]{3}{*}{$\begin{array}{l}\text { Bakgrunns- } \\
\text { breytur }\end{array}$} & \multicolumn{4}{|c|}{ PASE-heild } & \multicolumn{4}{|c|}{ PASE $_{\text {log }}$-frístundir } & \multicolumn{4}{|c|}{ PASE-heimili } & \multicolumn{4}{|c|}{${ }_{\text {PASE-vinna }}$ flokkar } \\
\hline & \multirow[b]{2}{*}{ B } & \multicolumn{2}{|c|}{$95 \%$ ÖM } & \multirow[b]{2}{*}{ p-gildi } & \multirow[b]{2}{*}{ B } & \multicolumn{2}{|c|}{$95 \%$ ÖM } & \multirow[b]{2}{*}{ p-gildi } & \multirow[b]{2}{*}{ B } & \multicolumn{2}{|c|}{$95 \%$ ÖM } & \multirow[b]{2}{*}{ p-gildi } & \multirow[b]{2}{*}{ 내 } & \multicolumn{2}{|c|}{$95 \%$ ÖM } & \multirow[b]{2}{*}{ p-gildi } \\
\hline & & NM & EM & & & NM & EM & & & NM & EM & & & NM & EM & \\
\hline Búseta & $-21,8$ & -45.1 & 1,49 & 0,066 & $-0,144$ & $-0,489$ & 0,2 & 0,408 & 10,4 & 21,598 & 1,83 & 0,069 & 0,45 & $-1,48$ & $-0,12$ & 0,022 \\
\hline Kyn & $-38,2$ & $-61,3$ & $-15,02$ & 0,001 & $-0,156$ & -0.502 & 0,19 & 0,375 & -14.1 & $-2,944$ & $-2,5$ & 0014 & 0,48 & $-1,43$ & $-0,03$ & 0.042 \\
\hline $\begin{array}{l}\text { Aldurs- } \\
\text { hópur }\end{array}$ & $-43,8$ & -67.1 & $-20,55$ & $<0,001$ & $-0,221$ & $-0,567$ & 0,125 & 0,209 & -11.7 & $-0,439$ & $-2,05$ & 0,042 & 0,23 & $-2,23$ & $-0,73$ & $<0,001$ \\
\hline
\end{tabular}

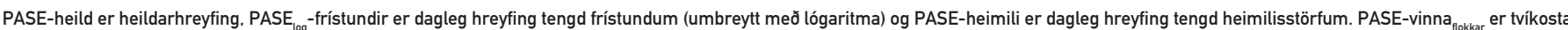
breyta par sem dagleg hreyfing er tengd vinnu sem reynir á líkamann. Allar bakgrunnsbreytur eru skoðađar saman í pessari fjölpátta aðhvarfsgreiningu í tengslum við hvern einstaka kvarða MLA. P-gildi <0,05 gefur til kynna marktækan mun eftir búsetu, kyni eða aldurshópi. Skammstöfunin ÖM stendur fyrir öryggismörk. NM fyrir neðri mörk, EM fyrir efri mörk og LH fyrir líkindahlutfall (odds ratio). 
Tafla IV. Punglyndiseinkenni og tengsl við daglega hreyfingu í mismunandi aðstæðum - einföld og fjölpátta línuleg aðhvarfsgreining.

\begin{tabular}{|c|c|c|c|c|c|c|c|c|c|c|}
\hline \multicolumn{6}{|c|}{ Punglyndiseinkenni: Samband einstakra kvarda PASE vid GDS $_{\log }{ }^{*}$} & \multicolumn{5}{|c|}{$\begin{array}{l}\text { Punglyndiseinkenni: Samband einstakra kvarda PASE og } \text { GDS }_{\log } \text { ad } \\
\text { teknu tilliti til bakgrunnsbreyta** }\end{array}$} \\
\hline \multirow[b]{2}{*}{ Skýribreytur } & \multirow[b]{2}{*}{ B } & \multirow[b]{2}{*}{ SF } & \multicolumn{2}{|c|}{$95 \%$ ÖM } & \multirow[b]{2}{*}{ p-gildi } & \multirow[b]{2}{*}{ B } & \multirow[b]{2}{*}{ SF } & \multicolumn{2}{|c|}{ 95\% ÖM } & \multirow[b]{2}{*}{ p-gildi } \\
\hline & & & NM & EM & & & & NM & EM & \\
\hline PASE-heild & $-0,003$ & 0.0007 & $-0,004$ & -0.001 & $<0.001$ & $-0,002$ & 0.0008 & -0.004 & -0.0009 & 0.002 \\
\hline PASE $_{\log }$-frístundir & $-0,017$ & 0,0602 & $-0,289$ & $-0,051$ & 0,005 & $-0,150$ & 0.0599 & -0.269 & $-0,0321$ & 0,013 \\
\hline PASE-heimili & $-0,003$ & 0,0016 & $-0,006$ & $-0,0001$ & 0,043 & $-0,003$ & 0.0016 & $-0,007$ & $-0,0001$ & 0,042 \\
\hline PASE-vinna $_{\text {flokkar }}$ & $-0,276$ & 0.1256 & $-0,524$ & $-0,028$ & 0,030 & $-0,208$ & 0.1320 & $-0,469$ & 0,0538 & 0.119 \\
\hline PASE $_{\text {log }}$-ganga & $-0,133$ & 0,0662 & -0.264 & $-0,002$ & 0,047 & $-0,110$ & 0.0654 & $-0,240$ & 0.0191 & 0,094 \\
\hline
\end{tabular}

*Hér var notuð einföld línuleg að̌hvarfsgreining. **Hér var notuð fjölpátta línuleg að̌hvarfsgreining. GDS eru stig úr Geriatric Depression Scale umbreytt með lógaritma. PASE-heild stendur fyrir heildarstig á Physical Activity Scale for the Elderly (PASE). PASE -frístundir fyrir stig tengd frístundum (umbreytt með lógaritma). PASE-heimili fyrir stig tengd heimilisstörfum, PASE-vinna tvíkosta breytu fyrir stig tengd vinnu sem reynir á líkamann eđa enga vinnu sem reynir á líkamann og PASE $_{\text {log }}$-ganga fyrir hreyfingu í frístundum sem tengist göngu (umbreytt med lógaritma). P-gildi $<0,05$ gefur til kynna marktækan mun. SF stendur fyrir stađalfrávik, ÖM fyrir öryggismörk. NM fyrir neđri mörk og EM fyrir efri mörk.

Tafla V. Punglyndiseinkenni og sjálfstæð tengsl peirra við daglega hreyfingu í mismunandi aðstæðum og bakgrunnsbreytur - fjölpátta línuleg aðhnvarfsgreining.

\begin{tabular}{|c|c|c|c|c|c|c|c|c|c|c|}
\hline \multicolumn{6}{|c|}{$\begin{array}{l}\text { Líkan a: Punglyndiseinkenni }\left(\text { GDS }_{\log }\right) \text { og sjálfstæð tengsl við prjá } \\
\text { undirkvarða á PASE }\end{array}$} & \multicolumn{5}{|c|}{$\begin{array}{c}\text { Líkan b: Punglyndiseinkenni }\left(\mathrm{GDS}_{\mathrm{log}}\right) \text { og sjálfstæð tengsl við prjá undirkvarða } \\
\text { á PASE að teknu tilliti til bakgrunnsbreyta }\end{array}$} \\
\hline \multirow[b]{2}{*}{ Skýribreytur } & \multirow[b]{2}{*}{ B } & \multirow[b]{2}{*}{ SF } & \multicolumn{2}{|c|}{ 95\% ÖM } & \multirow[b]{2}{*}{ p-gildi } & \multirow[b]{2}{*}{ B } & \multirow[b]{2}{*}{ SF } & \multicolumn{2}{|c|}{$95 \%$ ÖM } & \multirow[b]{2}{*}{ p-gildi } \\
\hline & & & NM & EM & & & & NM & EM & \\
\hline PASE $_{\log }$-frístundir & $-0,124$ & 0,0622 & $-0,247$ & $-0,001$ & 0,047 & $-0,1184$ & 0,0617 & $-0,24$ & 0,00363 & 0,057 \\
\hline PASE-heimili & $-0,002$ & 0,0017 & $-0,006$ & 0,001 & 0.174 & $-0,0028$ & 0,0018 & $-0,006$ & 0,0008 & 0.129 \\
\hline PASE-vinna flokkar & $-0,264$ & 0.1362 & $-0,533$ & 0,0058 & 0,055 & $-0,1889$ & 0.1415 & -0.469 & 0,0911 & 0.184 \\
\hline Búseta & & & & & & 0,16151 & 0.129 & $-0,094$ & 0,4167 & 0.213 \\
\hline Kyn & & & & & & $-0,1027$ & 0.1332 & $-0,366$ & 0.1608 & 0,442 \\
\hline Aldurshópur & & & & & & 0.2119 & 0.1367 & $-0,059$ & 0,4823 & 0.124 \\
\hline
\end{tabular}

GDS $S_{\text {og }}$ eru stig úr Geriatric Depression Scale, umbreytt með lógaritma og notuð sem svarbreyta í fjölpátta línulegri að̌hvarfsgreiningu. PASE-heild stendur fyrir heildarstig á Physical Activity Scale for the Elderly (PASE). PASE ${ }_{\text {log }}$-frístundir fyrir stig tengd frístundum (umbreytt með lógaritma). PASE-heimili fyrir stig tengd heimilisstörfum. PASE-vinna ${ }_{\text {flokkar }}$ fyrir tvíkosta breytu fyrir stig tengd vinnu sem reynir á líkamann eđa enga vinnu sem reynir á líkamann. Líkan a inniheldur prjá undirkvarđa PASE. Líkan b inniheldur bæđi prjá undirkvarða PASE og prjár bakgrunnsbreytur. P-gildi <0,05 gefur til kynna marktækan mun. Skammstöfunin SF stendur fyrir staðalfrávik, ÖM fyrir öryggismörk. NM fyrir neðri mörk og EM fyrir efri mörk.

er andstætt eldri íslenskri rannsókn ${ }^{22}$ og andstætt niðurstöðum úr útlendum rannsóknum par sem horft var sérstaklega til pessa aldurshóps. ${ }^{8,9,23}$ Раð að lyfjanotkun var meiri meðal péttbýlisbúa en dreifbýlisbúa er hins vegar samhljóða niðurstöðum rannsóknar á eldri Norðlendingum frá 2004. ${ }^{22}$ Almennt lýstu pátttakendur fáum punglyndiseinkennum en aðeins 16 af 175 (9\%) fóru yfir viðmið á GDS sem benda til punglyndis (11 eða fleiri stig af 30$)^{18}$ og enginn fór yfir 20 stig á GDS. Petta er til dæmis mun lægra en GDS-niðurstöður úr rannsóknum sem sýndu frá $12 \%$ og upp í 50\% algengi punglyndis meðal eldri borgara frá mismunandi löndum og úr ólíkum pjóðfélagshópum. ${ }^{24}$

Niðurstöðurnar sem snúa að daglegri hreyfingu eftir búsetu, kyni eða aldurshópi eru um margt sambærilegar niðurstöðum rannsóknar frá árinu 2004 á eldri Norðlendingum. ${ }^{5}$ Í hvorugri rannsóknanna var búsetutengdur munur á heildarhreyfingu og í báđum rannsóknum voru heimilisstörfin stærsta uppspretta líkamlegrar áreynslu. Í báđum rannsóknum var meira um hreyfingu við vinnu í dreifbýli en í péttbýli, og pátttakendur sem komu úr dreifbýli voru margir hverjir starfandi bændur og reyndu líkamlega á sig við pær aðstæður. Gagnaöflun beggja rannsókna náði yfir tímabil í lífi bænda sem einkennast af lengri törnum í líkamlegri áreynslu eins og slætti, göngum og sláturtíð. Раð að pátttakendur sem bjuggu í dreifbýli hreyfðu sig jafn mikið og péttbýlisbúar í frístundum er hins vegar í andstöðu við niðurstöður fyrri rannsókna par sem eldra fólk í dreifbýli hreyfði sig minna. ${ }^{5,10}$ Pessar niðurstöður geta bent til pess að eldri dreifbýlisbúar séu að verða meðvitaðri um mikilvægi daglegrar hreyfingar í frístundum og breyttra aðstæðna sem gefa tækifæri til frístundaiðju og hreyfingar. Í mörgum sveitarfélögum á Íslandi er nú reynt að styðja við hreyfingu eldra fólks í frístundum, meðal annars með fríu aðgengi í sund, framboði á hreyfingu í pjónustumiðstöðvum og vetraraðgengi að ípróttahúsum. ${ }^{25}$

Раð er pekkt að eldri karlar hreyfa sig meira en konur í heildina og tengt atvinnu, ${ }^{5,6}$ en óvenjulegra er að sjá karla hreyfa sig meira 
en konur í tengslum við heimilisstörf. Niðurstöðurnar benda til pess að peir eldri karlar sem tóku pátt í rannsókninni hafi verið nokkuð hraustir par sem peir sem hreyfðu sig mikið við heimilisstörf og hreyfðu sig einnig mikið í frístundum og vinnu. PASEheimili byggir á spurningum um pað hvort viðkomandi hafi sinnt viðhaldi á heimili og hirt lóðina, og við útreikninga á PASE-stigum vega pessir pættir pungt. Mögulegt er að karlar sinni pessum athöfnum frekar en konurnar ásamt pví að taka pátt í öðrum heimilisverkum. Pótt konur fengju færri PASE-heimili stig en karlar pá tengdist stærra hlutfall af heildarhreyfingu kvenna heimilisstörfum. Niðurstöður okkar eru samhljóða öðrum um að heimilisstörf skipi stóran og mikilvægan sess í daglegri hreyfingu eldra fólks. ${ }^{5,26-28}$

Раð аð 75-92 ára aldurshópurinn hreyfði sig minna en sá yngri, að teknu tilliti til kyns og búsetu, er í samræmi við aðrar rannsóknir par sem eldri pátttakendum hefur verið skipt í tvo aldurshópa. ${ }^{5,26}$ Óvenjulegra er að sjá að 75-92 ára hópurinn hreyfði sig jafnmikið í frístundum og peir sem voru á aldrinum 65-74 ára. Mögulega erum við að sjá fram á tíma par sem nýjar kynslóðir af fólki eldra en 75 ára eru farnar að venjast pví að hreyfa sig í frístundum. Einnig er mögulegt að fyrrnefndar aðgerðir sveitafélaganna ${ }^{25}$ séu að skila sér og efli slíkan lífsstíl.

Niðurstöðurnar styðja við pekkt samband á milli betri útkomu á GDS og meiri heildarhreyfingar annars vegar ${ }^{7,29}$ og hreyfingar í frístundum hins vegar, ${ }^{3,30}$ og pessi tengsl héldust stöðug pegar tekið var tillit til áhrifa búsetu, kyns og aldurshóps. Áhugavert er að sjá betri útkomu á GDS tengjast bæði meiri hreyfingu við heimilisstörf og vinnu, en GDS missti pessi tengsl við hreyfingu í vinnu pegar tekið var tillit til bakgrunnsbreytanna. Stærra úrtak hefði purft til að rannsaka mögulega gagnverkun og leita skýringar á pessum niðurstöðum. Hreyfing í frístundum (par með talið ganga) reyndist hafa sterkustu sjálfstæðu tengslin við minni punglyndiseinkenni pegar allir undirkvarðar PASE voru settir saman í eitt og sama líkanið, sem rímar við rannsóknarniðurstöður á 65-75 ára New York-búum par sem hreyfing tengd frístundum (ípróttir og ganga) hafði sterkari tengsl við minni punglyndiseinkenni en hreyfing tengd heimilisstörfum eða vinnu. ${ }^{7}$ Undir hreyfingu í frístundum fellur meðal annars markviss pjálfun en sýnt hefur verið fram á að hreyfing sem ætlað er að reyna markvisst á líkamann hefur jákvæð tengsl við geðheilbrigði og vinnur gegn vægu punglyndi, til dæmis á pann hátt að endorfín, líkamshiti og myndun hvatbera eykst. ${ }^{31}$ Enn er minna vitað um áhrif hreyfingar við heimilisstörf og atvinnu á pessa lífeðlisfræðilegu pætti og hvort breytileiki í hreyfingu sem tengist heimilisstörfum og vinnu sé allajafna nægur til að hægt sé að greina möguleg tengsl við vægt punglyndi.

Við túlkun á niðurstöðum rannsóknarinnar er mikilvægt að hafa eftirfarandi takmarkanir og styrkleika í huga: Par sem um pversniðsrannsókn er að ræða var ekki hægt að alhæfa um orsakasambönd og smæð úrtaksins jók líkur á villu af gerð II og tak- markaði möguleika á tölfræðigreiningum. Með pví að nota mælitæki sem byggja á ígildi samfelldra mælikvarða (PASE og GDS) nýttum við vel pað tölfræðiafl sem mögulegt var að ná miðað við stærð úrtaksins. Rannsókn á próffræðilegum eiginleikum PASE meðal eldra fólks í dreifbýli sýndi góðan áreiðanleika endurtekinna mælinga (Intraclass Correlation Coefficient 0,91) ${ }^{32}$ en ekki hefur verið rannsakað hvort punglyndi hefur áhrif á pað sjálfsmat sem krafist er í PASE og par með á áreiðanleika niðurstaðna. Pátttökuhlutfall (58\%) var ásættanlegt en 21 prósentustigi lægra en í lýðgrundaðri rannsókn á heilsutengdum högum eldri Norðlendinga frá 2004 (79\%). ${ }^{5}$ Pessi breyting á pátttökuhlutfalli er rannsóknarefni en hún gæti endurspeglað rannsóknapreytu meðal einstaklinga sem sögðust hafa tekið pátt mörgum rannsóknum og skoðanakönnunum upp á síðkastið og tregara aðgengi að einstaklingum í síma, en fyrir 15 árum voru öll símanúmer aðgengileg í símaskrá og símnúmerabirting var takmörkuð. Einnig er hætta á pví að punglyndari einstaklingar hafi síður áhuga, einbeitingu eða orku til að taka pátt í svo umfangsmikilli rannsókn, sem gæti skekkt niðurstöðurnar. Styrkleiki rannsóknarinnar liggur í lagskiptu lýðgrunduðu slembiúrtaki, notkun á stöðluðum alpjóðlegum mælitækjum til að nema lykilbreytur og pví að starfsmenn rannsóknarinnar hittu alla pátttakendur, sem auðveldaði pátttöku eldri einstaklinga með skerta sjón, heyrn og fínhreyfingar.

\section{Ályktun}

Heilsueflandi hreyfing á sér margskonar rætur en markviss hreyfing í frístundum virðist tengjast geðheilsu meira en hreyfing við aðrar aðstæður. Mikilvægt er að vera vakandi fyrir pví að eldra fólk sem glímir við punglyndi heldur sig mögulega frá frístundatengdri og markvissri hreyfingu. Pessar niðurstöður, og раð аð pekkja hvernig eldri einstaklingar hreyfa sig í daglegu lífi, geta nýst læknum og öðrum heilbrigðisstarfsmönnum sem ráðleggja um viðeigandi heilsueflandi hreyfingu. Pekking sem pessi skiptir máli fyrir stefnumótun stjórnvalda, heilbrigðisyfirvalda og sveitarstjórna par sem markmiðið er að efla heilsu eldri borgara og veita peim viðeigandi pjónstu sem vilja eldast heima.

\section{Pakkir}

Bestu pakkir til peirra sem tóku pátt í rannsókninni. Starfsmönnum rannsóknarinnar, peim Ölmu Dröfn Vignisdóttur, Pálu Sigríði Tryggvadóttur, Sigríði Atladóttur og Telmu Ýr Sigurðardóttur, eru pökkuð vel unnin störf við söfnun gagna. Aðilum úr rannsóknarhópnum, peim Elínu Díönu Gunnarsdóttur, Jóni Árna Steingrímssyni, Sonju Stelly Gústafsdóttur og Stefáni B. Sigurðssyni er pakkað fyrir peirra framlag til rannsóknarinnar. Rannsóknin var styrkt af Byggðarannsóknasjóði, Rannsóknasjóði Háskólans á Akureyri, Vísindasjóði Sjúkrahússins á Akureyri og B-hluta vísindasjóðs Félags íslenskra hjúkrunarfræðinga. 


\section{Heimildir}

1. Christensen K, Doblhammer G, Rau R, et al. Ageing populations: The challenges ahead. Lancet 2009; 374: 1196-208.

2. Alexopoulos GS. Depression in the elderly. Lancet 2005; 365: 1961-70.

3. Strawbridge WJ, Deleger S, Roberts RE, et al. Physical activity reduces the risk of subsequent depression for older adults. Am J Epidemiol 2002; 156: 328-34.

4. Bangsbo J, Blackwell J, Boraxbekk CJ, et al. Copenhagen Consensus statement 2019: Physical activity and ageing. Br J Sports Med 2019; 53: 856-8.

5. Arnadottir SA, Gunnarsdottir ED, Lundin-Olsson L. Are rural older Icelanders less physically active than those living in urban areas? A population-based study. Scand J Public Health 2009; 37: 409-17.

6. Notthoff N, Reisch P, Gerstorf D. Individual characteristics and physical activity in older adults: A systematic review. Gerontology 2017; 63: 443-59.

7. Joshi S, Mooney SJ, Kennedy GJ, et al. Beyond METs: types of physical activity and depression among older adults. Age Ageing 2016; 45: 103-9.

8. Baernholdt M, Yan G, Hinton I, et al. Quality of life in rural and urban adults 65 years and older: Findings from the National Health and Nutrition Examination survey. J Rural Health 2012; 28: 339-47.

9. Fogelholm M, Valve R, Absetz P, et al. Rural-urban differences in health and health behaviour: A baseline description of a community health-promotion programme for the elderly. Scand J Public Health 2006; 34: 632-40.

10. Deng Y, Paul DR. The relationships between depressive symptoms, functional health status, physical activity, and the availability of recreational facilities: A rural-urban comparison in middle-aged and older Chinese adults. Int J Behav Med 2018; 25: 322-30.

11. Sigurdardottir AK, Kristófersson GK, Gústafsdóttir SS, et al. Self-rated health and socio-economic status among older adults in Northern Iceland. Int J Circumpolar Health 2019; 78: 1697476

12. Sindradóttir JI, Harðarson O. Endurskilgreining Hagstofu Íslands á péttbýlisstöðum og byggðakjörnum. Hagtíðindi 2015; 2 .

13. Washburn RA, Smith KW, Jette AM, et al. The Physical Activity Scale for the Elderly (PASE): Development and evaluation. J Clin Epidemiol 1993; 46: 153-62.

14. Árnadóttir SÁ. Mat á líkamsvirkni aldraðra. Sjúkrapjálfarinn 2007; 4: 11-3.

15. Sattler MC, Jaunig J, Tösch C, et al. Current evidence of measurement properties of physical activity questionnaires for older adults: An updated systematic review. Sports Med 2020; 50: 1271-315.

16. Yesavage JA, Brink TL, Rose TL, et al. Development and validation of a geriatric depression screening scale: a preliminary report. J Psychiatr Res 1982;17(1):37-49.
17. Valdimarsdóttir M, Jónsson JE, Einarsdóttir $\mathrm{S}$, et al. Punglyndismat fyrir aldraða - íslensk gerð Geriatric Depression Scale (GDS). Læknablaðið 2000; 86: 344-8.

18. Brink TL, Yesavage JA, Lum O, et al. Screening tests for geriatric depression. Clin Gerontol 1982; $1: 37-43$.

19. Podsiadlo D, Richardson S. The timed "Up \& Go": A test of basic functional mobility for frail elderly persons. J Am Geriatr Soc 1991; 39: 142-8.

20. Embætti landlæknis. Aldraðir á hjúkrunar- og dvalarheimilum. Talnabrunnur - Fréttabréf landlæknis um heilbrigðisupplýsingar. 2016; 10: 1-4.

21. Sigbjörnsdóttir HB, Eiríksdóttir VH. Lýðheilsuvísar eftir heilbrigðisumdæmum - Umfjöllun og skilgreiningar. Embætti landlæknis, Reykjavík 2020.

22. Sigurðardóttir ÁK, Árnadóttir SÁ, Gunnarsdóttir ED. Lyfjanotkun eldri Íslendinga sem búa heima. Lýðgrunduð rannsókn í dreifbýli og péttbýli. Læknablaðið 2011; 97: 675-80.

23. Monnat SM, Beeler Pickett C. Rural/urban differences in self-rated health: Examining the roles of county size and metropolitan adjacency. Health Place 2011; 17: 311-9.

24. Mui AC, Kang SY, Chen LM, et al. Reliability of the Geriatric Depression Scale for use among elderly Asian immigrants in the USA. Int Psychogeriatr 2003; 15: 253-71.

25. Snæfríðar- og Gunnarsdóttir H, Tryggvadóttir G, Gústafsdóttir G. Kortlagning á pjónustu við aldraða. Félagsvísindastofnun Háskóla Íslands, Reykjavík 2020

26. Tsunoda K, Soma Y, Kitano N, et al. Age and gender differences in correlations of leisure-time, household, and work-related physical activity with physical performance in older Japanese adults. Geriatr Gerontol Int 2013; 13: 919-27.

27. 27. Mooney SJ, Joshi S, Cerda M, et al. Patterns of physical activity among older adults in New York City: A latent class approach. Am J Prev Med 2015; 49: e13-22.

28. Murphy MH, Donnelly P, Breslin G, et al. Does doing housework keep you healthy? The contribution of domestic physical activity to meeting current recommendations for health. BMC Public Health 2013; 13: 966

29. Aktürk Ü, Aktürk S, Erci B. The effects of depression, personal characteristics, and some habits on physical activity in the elderly. Perspect Psychiatr Care 2019; 55: 112-8.

30. Schuch FB, Vancampfort D, Rosenbaum S, et al. Exercise for depression in older adults: A meta-analysis of randomized controlled trials adjusting for publication bias. Braz J Psychiatry 2016; 38: 247-54

31. Mikkelsen K, Stojanovska L, Polenakovic M, et al. Exercise and mental health. Maturitas 2017; 106: 48-56.

32. Dinger MK, Oman RF, Taylor EL, et al. Stability and convergent validity of the Physical Activity Scale for the Elderly (PASE). J Sports Med Phys Fitness 2004; 44: 186-92.

\section{Physical activity and depression among older community-dwelling adults in urban and rural areas: Population based study}

\section{Birgitta R. Smáradóttir \\ Gísli K. Kristófersson² \\ Árún K. Sigurđardóttir ${ }^{2.3}$ \\ Sólveig Á. Árnadóttir ${ }^{1.4}$}

Correspondence: Sólveig Á. Árnadóttir, saa@hi.is

Key words: Physical activity, depression, ageing, urban, rural.

'Department of Physical Therapy, School of Health Sciences, University of Iceland, ${ }^{2}$ School of Health Sciences, University of Akureyri, Akureyri, Iceland, ${ }^{3}$ School of Health Sciences, University of Akureyri, Akureyri, Iceland; Akureyri Hospital, Akureyri, Iceland, ${ }^{4}$ Research Centre of Movement Science, Department of Physical Therapy, University of Iceland.
INTRODUCTION: The aim was to explore physical activity (PA) in different daily contexts, among older adults in Northern Iceland; and by urban-rural living, age-group and sex. Moreover, to study the association between PA and depression.

MATERIAL AND METHODS: The study was cross-sectional, population based and data was collected in 2017-'18 in Northern Iceland. The 175 community-dwelling participants (participation rate $59.7 \%$ ) were $65-92$ years old, $43 \%$ were women, and $40 \%$ lived in rural areas. The Physical Activity Scale for the Elderly (PASE) was used to obtain a total PA score and three subs-scores reflecting PA associated with leisure-time, household and work. The Geriatric Depression Scale was used to detect depressive symptoms.

RESULTS: Total PA was the same for urban and rural people, men were more active than women, and the 65-74 years age-group was more active than the 75-92 years age-group. People in rural areas were more likely to do work-related PA than people in urban areas, as was the 65-74 years age-group compared to the 75-92 years age-group. Men were more PA during household than women. Higher total PA and the sub-scores of PASE had significant association with fewer depressive symptoms. PA in leisure-time was the only PASE sub-score with a significant and independent association with fewer depressive symptoms.

CONCLUSION: The results improve the knowledge on PA among older community-dwelling adults, and its relationship with depressive symptoms. Although PA in different contexts has various health benefits, an emphasis on leisure-time PA may have the most beneficial effect on mental health. 